\title{
The energy transect; including sustainability issues in urban morphology analyses
}

\author{
E. Troglio, T. Haas, T. Martschenko \& S. Pagluila \\ Department of Urban Planning and Environment, \\ KTH, The Royal Institute of Technology, Sweden
}

\begin{abstract}
To tackle climate change, pollution and dwindling resources, we need to rethink our urban environment by identifying the most suitable morphological structures, with an optimized local (cradle-to-cradle) approach to energy and resources; towards economic feasibility and improved environmental quality.

In this paper we propose integrating the Transect concept with the energy issues, to provide a flexible system for allocating building types, landscaping, energy systems, etc. so that they contribute to a symbiotic ecosystem. This Transect framework can include a juxtaposed toolbox that can be used collectively at the region, city, sector, neighborhood, and block/building scale. Keywords: urban planning, morphology, transect, energy, existing buildings, land use, typology.
\end{abstract}

\section{Energy issues in urban areas}

Large parts of the world population (50-60\%) are presently living in urban areas, which represent the most energy consuming systems (The World Bank, 2009). Of the many studies conducted, the one carried out by the International Energy Agency IEA [1] showed that cities have an average energy consumption of $69 \%$ of the total energy needed for human activities; by 2030 this level will increase to $75 \%$. Moreover, the built environment is responsible of one fifth of the all greenhouse gases emissions IPCC [2], explained by the fact that most humanrelated activities are located in buildings.

The existing building stock is responsible for $40 \%$ of the used global primary energy. Although the contribution of existing technologies for energy saving and production are widely recognized, the potential energy savings due to retrofitted 
cities is hugely unexploited IEA [1]. Block and neighborhood design play a substantial role in controlling urban energy demand and energy production through adaptation to local climatic conditions and identification of the most suitable morpho-typological structures (Ratti et al. [3]). A coherent organization of the city and its parts can significantly contribute in energy savings (Jenks and Burton [4]), in terms of energy used for the production of goods and services, car-trip reduction through the study of an efficient network of public transport, cutback of energy demand for climate control, decrease of local energy peaks thanks to functional mix.

Our cities need to achieve integration between urban and energy design, with a cycle approach to energy (consumption and production) and materials, optimizing local resources towards economic feasibility and environmental quality (Droege [5]).

\section{Urban morphology in an energy perspective}

Urban history has been influenced by the availability of resources within the cities' spheres of influence. From an evolutionary perspective, these relationships showed a correlation between energy systems and urban morphology. Complex social and economic systems emerged through the control and storage of increasing energy flows (Basalla [6] and Smil [7]). Prior to oilbased energy production, urban energy sources were primarily based on solar energy embodied in biomass and the work done by humans and animals; wind and water power to a lesser extent. Perlin [8] describes the historic relationship between urban grown, economic development and biomass exploitation thus: "Ancient writers observed that forests always recede as civilizations develop and grow $[\ldots]$ conversely, when a society declines, forests tend to regenerate".

Coal, and later oil, removed the limits to growth (number and size) of urban centers allowing for the development of the "oil city model" (De Pascali [9]) where access to energy and food were no longer restraints to growth. Since then, inexpensive energy has permitted the radical loosening of urban compactness and functional mix toward dispersed and highly specialized organizations (Burchell and Listokin [10]).

The design of urban areas without regard to local conditions and energy availability, which were originally seen as freedom of choice and development, need to be rethought in the face of peak oil and climate changes. As we have moved from a concentrated use of scattered energy resources (biomass, wind, water, animal/human) to a scattered use of concentrated resources (fossil), our next step is to again adapt our urban environments to the local conditions, combining urban form with available renewable energies, thus creating global cities based on local resources.

Generally, when considering historical cities, it was usually the vernacular architecture rather than the morphology that responded to local climatic and geomorphological conditions. Many of the energy conserving strategies have been in use for centuries; we merely need to update them. Passive technology should be explored before recommending high-tech solutions. 
Energy savings from counteracting the heat island effect can be substantial. The value of urban trees should not be underestimated. A 3-year study of the energy aspect of trees in Chicago showed that they contributed significantly to the removal of air pollutants, the sequestration of carbon. Increasing tree cover by $10 \%$ would lead to moderated temperatures, wind speeds, and a $5-10 \%$ decrease in heating and cooling cost; in turn reducing power plant emissions. (MacPherson et al. [11]).

In southern climates specifically, low albedo building finishes are crucial to decreasing the heat island effect. This could be extended to the road surfaces as well, substituting permeable surfaces for asphalt to the greatest extent possible, especially in large parking areas.

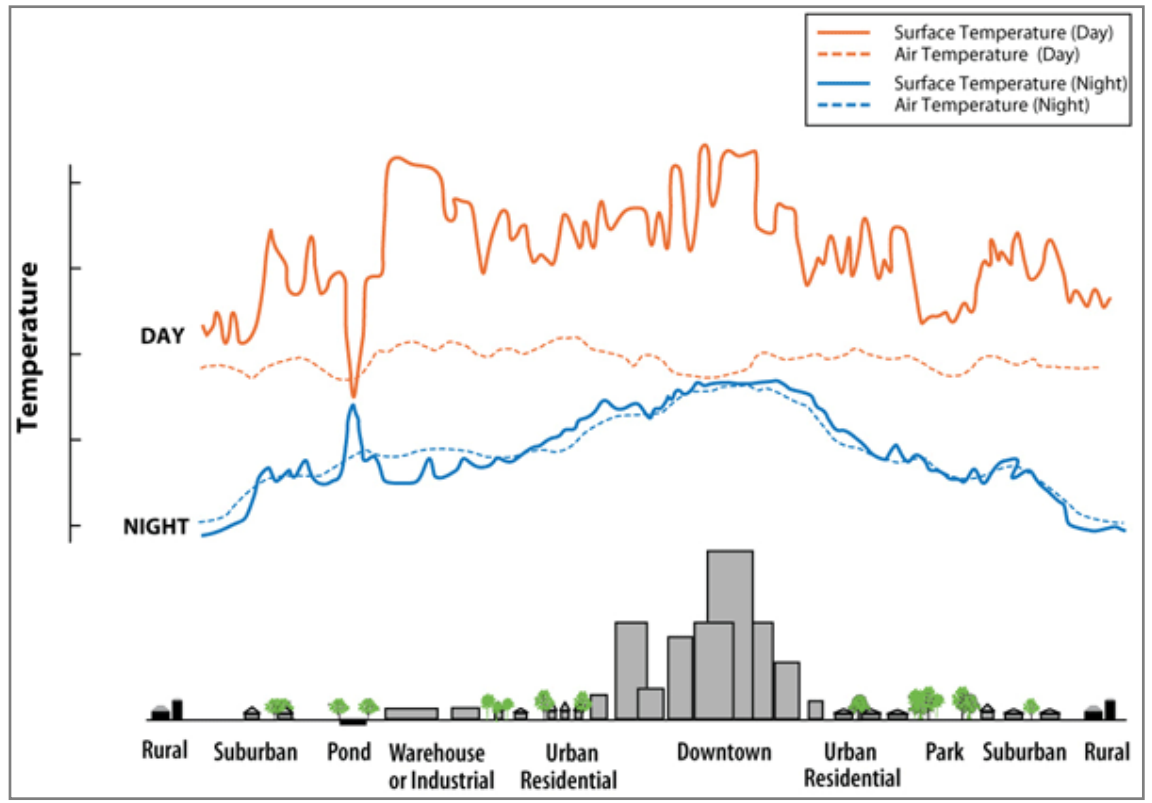

Figure 1: Scheme of the heat island effect profile according with urban morphology; the temperatures shown refer to a late summer afternoon EPA [12] modified from Voogt [13].

The siting, spacing and building shape greatly influence the amount of potential solar gain. Depending on the environment, these strategies can be used for optimizing or minimizing the availability of direct sunlight. The solar photovoltaic panels on the roofs should be aligned with the optimal position of the sun, regardless of the orientation of the building. Light shelves and solar tubes could distribute available sunlight into the centre of the buildings.

In an Italian study of morphology, travel modes and environmental impact (Camagni et al. [14]) it was shown that "wisely compact", mixed use, polycentric urban morphology was the most efficient in determining optimal transportation choices as it pertained to transportation related energy use. A New 
Zealand study from Krumdieck et al. [15], regarding post-peak oil scenarios suggests that travel will be incrementally prioritized and those living in concentrated activity areas with transit linked integrated mixed use cities would be less affected by decreasing fossil fuel availability.

Wind power in the urban context has been debated. Clearly this strategy is dependent on local factors and testing for optimal orientation and design. With increasing dependence on alternative power sources, costs for this technology should drop significantly to make urban-based wind power generation a viable option (Grant et al. [16]).

In North America, considering the embedded energy savings in the use of local materials during construction is underestimated. It's a widely accepted practice in much of the rest of the world to utilize the aggregates that are excavated during the initial stages of construction, also using the soils carefully mixed with binders as a construction material. EU policies enable maximal reuse of demolition material. While aiming for true cradle-to-cradle efficiency approaching $100 \%$, several countries have achieved recycling rates of over $60 \%$, looking for an EU target of 70\% by 2020 (FIR [17]).

\section{The energy transect}

As most of urban planning and design goals are interrelated today, due to a number of converging crises within urban development, issues of reduced car use, energy efficiency, increased density, and mixed-use development become pertinent (Farr [18] and Haas [19]). When we start to focus on dividing the land into separate uses, we are not just confronted with issues of numerous categories and divisions but also of an old fashioned view of the urban landscape. On the other hand, if we focus on the complexity of our environment, the systemic structure and the overall form and identity that we would like to have for our land and cities, we can start to use methods and classifications that are more flexible but that also understand the complexity providing our citizens, planners and developers the flexibility to create special and more livable places. The Transect categorization, evaluation and assessment system for design is really a model - an empowering tool for communities to create and maintain sustainable places (Emerson [20], Low [21], and Thadani [22]). The Transect uses descriptive but also a system of land use in order the manmade environment into a sequence of human habitats that flow from rural to urban zones, creating immersive environments (Coyle [23]). Each of these human habitats has a specific character with unique attributes and inhabitants, yet is also part of a network of other habitats that form a sustainable, cohesive system spatially, environmentally, traffic and energy wise. In general, the Transect uses the following six zones, each of which can be adapted to local goals and character: 1) Rural Preserve, 2) Rural Reserve, 3) Sub-Urban, 4) General Urban, 5) Urban Centre, and 6) Urban Core (Duany [24] and Thadani [22]). Each of these zones addresses critical planning elements such as land use, roads, infrastructure, development, open space, energy, wastewater, and vegetation (Duany [24], Duany and Talen [25], Bohl and Plater-Zyberk [26]). 
Whether working on a new development or existing urban patterns, interconnected design aspects need to be considered. The transect diagram can be a useful device for explaining the intertwined components of coherent urban patterns in the transformation towards the new realm of the renewable city.

Our investigation of the role of energy in urban morphology analyzed the components at the smallest scale; the typologies. The heat energy performances of buildings are related to form/dimension and age. The first parameter, which embodies concepts of compactness and complexity of the building form (Olgyay [27]), describes the heat exchange relations between a structure and the surrounding environment. The second parameter shows the role of materials, technology and energy regulations towards improving energy performances.

Table 1 shows the data from sample buildings in a medium sized north European city transect. As the data shows, both form (typology) and materials (technology) have a clear influence on heat energy reduction. Although technologies play an important part, the form effect is still clearly readable, with detached houses consuming twice the resources compared to towers or courtyard buildings.

Table 1: Estimated average annual power use relative to form $(\mathrm{kWh} / \mathrm{Sq} \mathrm{m} /$ year) for buildings in Lund, Sweden.

\begin{tabular}{|c|c|c|c|c|c|c|c|c|c|c|}
\hline $\begin{array}{l}\text { Year } \\
\text { Built }\end{array}$ & $\begin{array}{c}\text { Special } \\
\text { Buildings }\end{array}$ & $\begin{array}{c}\text { Tower } \\
\text { Buildings }\end{array}$ & $\begin{array}{l}\text { Courtyard } \\
\text { Blocks }\end{array}$ & $\begin{array}{l}\text { High Slab } \\
\text { Buildings }\end{array}$ & $\begin{array}{l}\text { Courtyard } \\
\text { Buildings }\end{array}$ & $\begin{array}{l}\text { Low } \\
\text { Tower } \\
\text { Buildings }\end{array}$ & $\begin{array}{l}\text { Row } \\
\text { Houses }\end{array}$ & $\begin{array}{l}\text { Low Slab } \\
\text { Buildings }\end{array}$ & $\begin{array}{c}\text { Detached } \\
\text { Houses }\end{array}$ & kWhr/sq.m./year \\
\hline \multirow{2}{*}{$\begin{array}{l}1910- \\
1930\end{array}$} & \multirow{2}{*}{145} & \multirow{2}{*}{138} & \multirow{2}{*}{184} & \multirow{2}{*}{188} & \multirow{2}{*}{172} & \multirow{2}{*}{193} & \multirow{2}{*}{261} & \multirow{2}{*}{ N/A } & \multirow{2}{*}{285} & $255-290$ \\
\hline & & & & & & & & & & $220-254$ \\
\hline \multirow{2}{*}{ 1931- 1975} & \multirow{2}{*}{91} & \multirow{2}{*}{124} & \multirow{2}{*}{113} & \multirow{2}{*}{121} & \multirow{2}{*}{164} & \multirow{2}{*}{194} & \multirow{2}{*}{166} & \multirow{2}{*}{ N/A } & \multirow{2}{*}{266} & $185-219$ \\
\hline & & & & & & & & & & $150-184$ \\
\hline \multirow{2}{*}{ 1976- 1995} & \multirow{2}{*}{ N/A } & \multirow{2}{*}{49} & \multirow{2}{*}{54} & \multirow{2}{*}{66} & \multirow{2}{*}{66} & \multirow{2}{*}{ N/A } & \multirow{2}{*}{72} & \multirow{2}{*}{85} & \multirow{2}{*}{108} & 115-149 \\
\hline & & & & & & & & & & $80-114$ \\
\hline \multirow{2}{*}{$\begin{array}{l}1997- \\
2007\end{array}$} & \multirow{2}{*}{40} & \multirow{2}{*}{39} & \multirow{2}{*}{47} & \multirow{2}{*}{48} & \multirow{2}{*}{$\mathbf{N} / \mathbf{A}$} & \multirow{2}{*}{51} & \multirow{2}{*}{75} & \multirow{2}{*}{74} & 81 & $45-79$ \\
\hline & & & & & & & & & & $<44$ \\
\hline
\end{tabular}

Identifying the role played by age, technology and building form constitutes only the starting point of the design and analysis of a renewable city. To describe the relations between different urban morphologies and their energy and environmental performances - and thus the interactions between buildings, open spaces and the urban grid, we have juxtaposed five major analysis issues to the transect.

The new "Energy Transect" is a forward-looking design tool for the development of a sustainable and systemic environmental vision for cities, towns and regions. The five areas of interest - morphology, land use, mobility, urban natural areas and block energy characteristics - define a first set of tools for reading the connections between urban morphologies and their main impacts on energy. The different transect morphologies or cells are the units for analysis, which allow a constant overview of the existing relationships, as well as guide the design process. The use of these cells increases the understanding and controls the interactions between them, both on a local and global scale. 
Five urban patterns are analyzed here: city core, dense city, modernist 1980's2000's, special districts and suburban areas. Each of them represents not only a different stage of the city's evolution, but also relations and drawbacks with the energy and environmental aspects, embodied in the morphologies and the concepts that generated them.

The first area of analysis, morphology, is conceived as a traditional Transect, highlighting the main conceptual characteristics of the urban patterns, as well as the section of them, and identifying the relations between buildings, open spaces, and greenery (Figure 2).

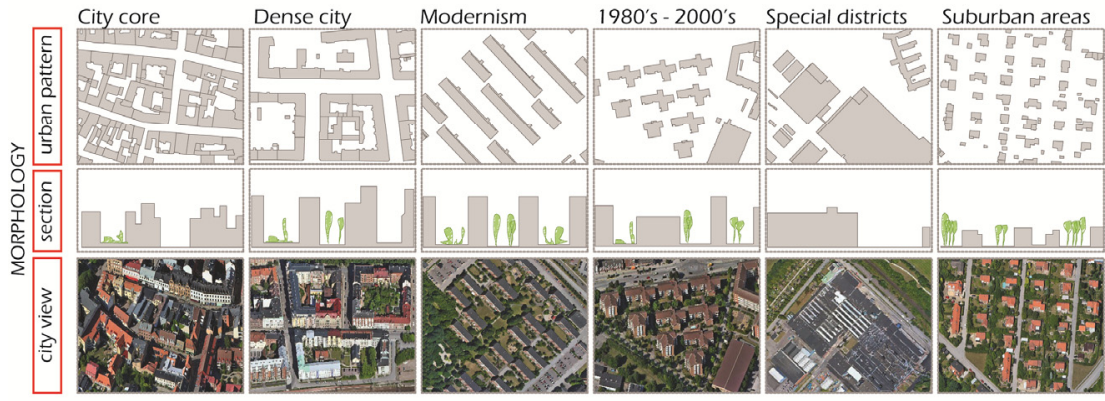

Figure 2: Different morphologies along the transect, from the dense city to the scattered suburban developments.

Land use (Figure 3) describes the complexity of the different patterns in terms of mix and spatial distribution of functions, which have an important role in controlling the energy peaks and improving the feasibility for distributed energy resources (Holden and Norland [28]), as well as supporting a sound social life and activities (ESCTC [29]). These schemes highlight the complexity of the distribution patterns and ease the comparison between different systems. Moreover, the land cover is included, highlighting built density and footprint, responsible - among others drawbacks - for the heat island effect (Oke [30]), and run off phenomena (Fiumi and Rossi [31]).



Figure 3: Visualization of the land use mix and land cover of the different morphologies. 
Figure 4 shows the proportion of the different transportation modes. The dense city core of European cities is generally characterized by high walkability and public transport, while cars are often kept away to improve quality of life and public spaces, and to control pollution. On the contrary, suburban areas have difficulties supporting walkability and public transport, due to the disperse pattern and the predominant mono-functionality (Newman and Kenworthy [32]). Though morphology influences the transport modal choices, income and family characteristics have a strong effect in the share of different means, which need to be included to produce effective car usage reduction policies (Dieleman et al. [33]).

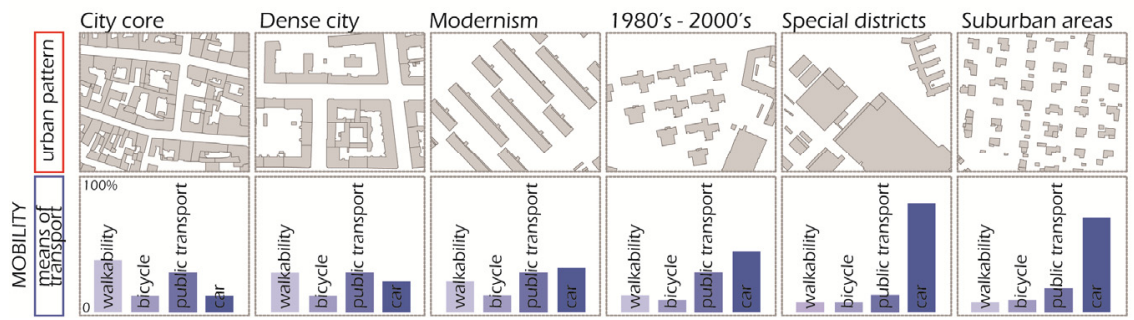

Figure 4: The transport modal split can be analyzed for each morphology, evaluating the sustainability of the different morphologies.

The role of green in improving energy performances of urban settlements, decreasing pollution and enhancing quality of life, is described in the three main parameters that constitute urban natural areas (Figure 5). By using different schemes it is possible to simultaneously describe different parameters that influence both energy performance and environmental quality of urban areas.

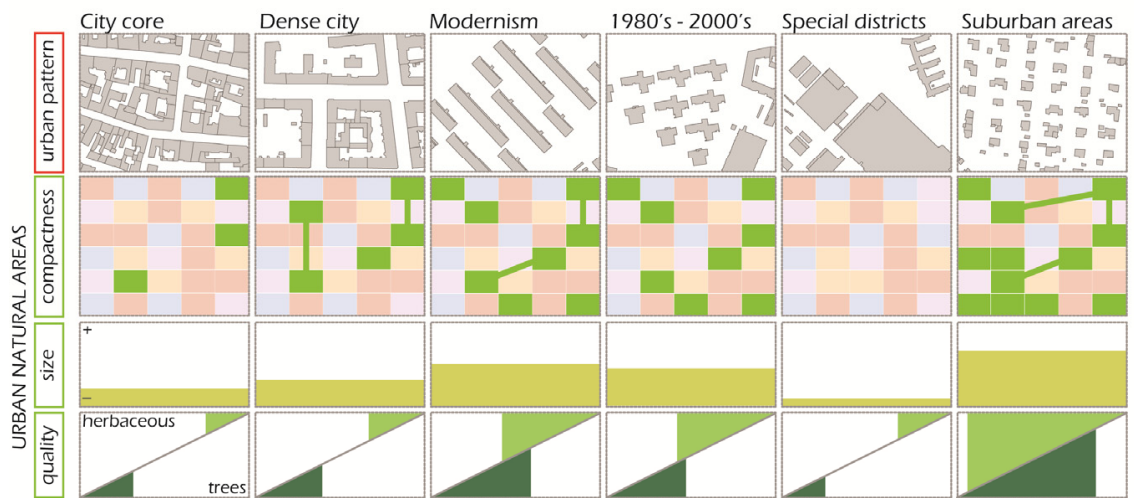

Figure 5: Analyses of the characteristics of urban natural areas in terms of connectivity, size and quality. 
In identifying compactness, extension and quality of urban natural areas in relation with morphology, it is possible to set a clear framework for actions that maximize the benefits of an interconnected net of green areas. Trees and gardens, as well as green roofs, contribute to reduce the summer heat (thus reducing the need of cooling) by controlling the microclimate (Arnfield [34], Akbari et al. [35]), protect from winds (Givoni [36]), reduce the air pollutants (Ratti et al. [37]), and prevent run-off effects and floods (Girling and Kellett [38]).

The block energy characteristics are strongly related with the specific evolution of the cities, and depend both on the urban grid and the adopted retrofitting policies. The values represent the average condition of European cities, with the historical centers characterized by older buildings, a general scarcity of solar radiation and a predominance of compact built form (Figure 6).

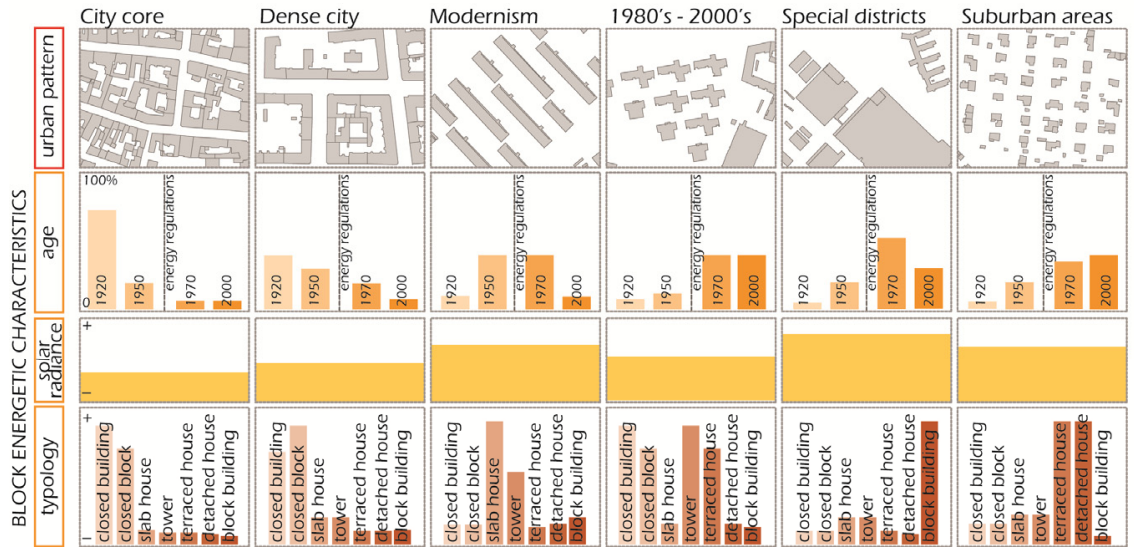

Figure 6: Age, solar radiance level, and typology mix of the different urban morphologies can greatly influence the energetic performances.

\section{Conclusions: use and innovation in the planning and design of cities}

Understanding the energy characteristics of urban areas through the transect contributes to the value of Sustainable Urbanism, which can then be viewed as a new and emerging framework for interdisciplinary urban planning, design, and management of cities, neighborhoods, and urban blocks by focusing on the processes that shape the form and function of the built environment in its full complexity (Farr [18]). The synergy of multi-modal transportation, sustainable economics, ecology and natural resource management, socio-cultural aspects, and physical-urban form become crucial for creating livable cities and communities of place that, together with their hinterlands, produce sustainable metropolitan-regional cities (Haas [19]). 
Increasing density decreases the need for Greenfield development and encourages infill and Brownfield development, thus preserving natural areas and biodiversity.

More than the size, the internal organization and management of a city - and the connections with its region - are key elements for providing the necessary environmental and socio-economical conditions (Nijkamp and Perrels [39]) which support urban services and functions (Hardoy et al. [40]).

In table 1 we showed the importance of the form factor. If we add the design of well connected urban grids, this implies that single high energy efficiency building located in an inefficient grid, does not exploit its potentials: while living in a performing building at a distance from a dense interconnected district, we might need more energy to reach services, travel, as well as embedded infrastructure energy.

The value of using Transect becomes even more important in that respect as the keys of sustainable urbanism have to do with the neighborhood, the edge and center, biophilia, high performance buildings and infrastructure, walkability, LEED certifications, form based codes and light imprints, etc. (Farr [18], Duany, et al. [41]). The Energy Transect becomes the foundation for defining density and human access to nature as well as design and energy saving schemes, leading new parameters to overlay with the city morphology (Troglio et al. [42]). Using the transect methodology requires calibration to local character and context as well as to the needs of each area in terms of energy, traffic, and other infrastructures (Coyle [23]). The transect diagram, aside from the explanatory value and practical utility, is a useful device for explaining the components of coherent urban patterns and improving their energy performances (Duany [24], Bohl and Plater-Zyberk [26]).

We need thus to refer to densification and compact cities as elements that support energy reduction, but we need to cope with cost and feasibility of modifying all the cities towards (Frey [43]), and the intrinsic long time of this transformation (Saglie [44]).

\section{References}

[1] IEA, Promoting energy efficiency investments. Case studies in the residential sector, OECD/IEA and AFD, Paris, 2008.

[2] IPCC, Climate Change 2007: Synthesis Report (Summary for Policymakers), Geneva, 2007.

[3] Ratti, C., Baker, N., Steemers, K., Energy Consumption and Urban Texture. Energy and Buildings, 37, pp. 762-776, 2004.

[4] Jenks, M., Burton, E., Achieving sustainable urban form, London, Spoon press, New York, 2000.

[5] Droege, P., The Renewable City: A comprehensive guide to an urban revolution, Wiley: New York, 2006.

[6] Basalla, G., Energy and Civilization, in Science, Technology and the Human Prospect, Chauncey Starr ed., Pergamon Press, 1980.

[7] Smil, V., Energy in World History, Westview Press, 1994. 
[8] Perlin, J., A forest journey. The story of wood and civilization, The Countryman Press: Woodstock, Vermont, 2005.

[9] De Pascali, P., Città ed energia. La valenza energetica dell'organizzazione insediativa, Franco Angeli, Milano, 2008.

[10] Burchell, R., Listokin, D., Energy and Land use, Center for Urban Policy Research, Rutgens, The State University of New Jersey, 1982.

[11] MacPherson, E.G., Nowak, D.J., Rowntree, R.A., eds., Chicago's Urban Forest Ecosystem; Results of the Chicago Urban Forest Climate Project, General Technical Report NE-186. United States Department of Agriculture, Forest Service, Northeastern Forest Experimental Station, 1994, Online http:/www.csu.edu/cerc/documents/ChicagosUrbanForest Ecosystem-ResultsoftheChicagoUrbanForestClimateProject.pdf

[12] EPA, http://www.epa.gov/hiri/about/index.htm

[13] Voogt, J. A., Urban heat island. Encyclopedia of Global Environmental Change, ed. Douglas, I., John Wiley \& Sons, New York, pp. 660-666, 2002.

[14] Camagni, R., Gibelli, M.C., Rigamonti, P., Urban mobility and urban form; the social and environmental costs of different patterns of urban expansion. Ecological Economics, 40, Elsevier, pp. 199-216, 2002.

[15] Krumdieck, S., Page, S., Dantas, A., Urban from and long-term fuel supply decline: A method to investigate the peak oil risks to essential activities. Transportation research Part a, 44, Elsevier, pp. 306 - 322, 2010.

[16] Grant, A., Johnstone, C., Kelly, N., Urban wind energy conversion: the potential of ducted turbines, 2008, Online http://strathprints.strath.ac.uk 15672/1/strathprints005672.pdf

[17] FIR - International Recycling Federation, FIR - representing the European recycling industry of $C \& D W, 2008$, Online http://www.fir-recycling.nl /files/FIR Brochure 2008.pdf

[18] Farr, D., Sustainable Urbanism: Urban Design with Nature, Wiley, 2007.

[19] Haas, T. (ed.), Introduction to Sustainable Urbanism in Sustainable Urbanism \& Beyond: Rethinking Cities for the Future, NY Rizzoli, 2012.

[20] Emerson, C., The SmartCode Solution to Sprawl, Washington DC Environmental Law Institute, 2007.

[21] Low, T.E., Light Imprint Handbook: Integrating Sustainability and Community Design, Civic by Design, Charlotte NC, 2010.

[22] Thadani, D., The Language of Towns \& Cities, Rizzoli, 2011.

[23] Coyle, S. J., Sustainable and Resilient Communities: A Comprehensive Action Plan for Towns, Cities and Regions, NY Wiley, 2011.

[24] Duany, A., Transect Planning. Journal of the American Planning Association, 68(3), American Planning Association, pp. 245-266, 2002.

[25] Duany, A., Talen, E., (eds.), Special Issue: The Transect. Journal of Urban Design, 7(3), 2002.

[26] Bohl, C., Plater-Zyberk, E., (eds), Building Community Across the Transect. Places, 18(1), 2006.

[27] Olgyay, V., Design with climate: bioclimatic approach to architectural regionalism, Princeton University Press, Princeton, 1973. 
[28] Holden, E., Norland, I.T., Three Challenges for the Compact City as a Sustainable Urban Form: Household Consumption of Energy and Transport in Eight Residential Areas in the Greater Oslo Region. Urban Studies, 42, Sage Publications, 2005.

[29] ESCTC - The European Sustainable Cities \& Towns Campaign, Charter of European Cities \& Towns Towards Sustainability - The Aalborg Charter, European Conference on Sustainable Cities \& Towns, Aalborg, Denmark, 27 May, 1994.

[30] Oke, T. R., The energetic basis of the urban heat island. Quarterly Journal of the Royal Meteorological Society, 108, pp. 1-24, 1982.

[31] Fiumi, L., Rossi S., Dalla cartografia storica al telerilevamento: la città di Roma, Edizione CNR - Pagine, Roma, 2007.

[32] Newman, P.W.G., Kenworthy, J.R., Sustainability and Cities: Overcoming Automobile Dependence, Island Press: Washington, D.C., USA, 1999.

[33] Dieleman, F.M., Dijst, M., Burghouwt, G., Urban Form and Travel Behaviour: Micro-level Household Attributes and Residential Context. Urban Studies, 39(3), pp. 507-527, 2002.

[34] Arnfield, A. J., Two decades of urban climate research: a review of turbulence, exchanges of energy and water, and the urban heat island. International Journal of Climatology, 23, pp. 1-26, 2003.

[35] Akbari, H. S., Davis, S., Dorsano, S., Cooling Our Communities: A Guidebook on Tree Planting and Lightcolored Surfacing, US Environmental Protection Agency Guidebook, Washington, DC, 1992.

[36] Givoni, B., Climate considerations in building and urban design, Van Nostrand Reinhold: New York, 1998.

[37] Ratti, C., Di Sabatino, S., Britter, R., Urban texture analysis with image processing techniques: winds and dispersion. Theoretical and Applied Climatology, Springer-Verlag, 2005.

[38] Girling, C., Kellett, R., Skinny Streets and Green Neighborhoods: Design for Environment and Community, Island Press, 2005.

[39] Nijkamp P., Perrels A., Sustainable cities in Europe: a comparative analysis of urban energy environmental policies, Earthscan: London, 1994.

[40] Hardoy, J. E., Mitlin, D., Satterthwaite, D., Environmental problems in Third World cities, Earthscan: London, 1992.

[41] Duany, A., Speck, J, Lydon, M., The Smart Growth Manual, NY, McGrawHill, 2010.

[42] Troglio, E., Doni, M., Haas, T., Urban typologies and heat energy demand. A case-study in the Italian context, 51st European Congress of the Regional Science Association International, Barcelona, Spain, August 30 September 3, 2011.

[43] Frey, H., Designing the city: towards a more sustainable urban form, E \& FN Spon: London, 1999.

[44] Saglie, I.L., Density and town planning. Implementing a densification policy, Dr.ing. thesis, Oslo School of Architecture, Nibr 4-98, 1998. 